\title{
PENGARUH MEDIA GAMBAR SKETSA TERHADAP KETERAMPILAN MENULIS KARANGAN DESKRIPSI DI SEKOLAH DASAR
}

\author{
Anriyani \\ Institut Agama Islam Negeri Palopo \\ Jl. Agatis I, Balandai, Bara, Kota Palopo, Sulawesi Selatan 91914 \\ E-mail: yanianriyani25@gmail.com
}

\begin{abstract}
This study aims to determine the form of application of sketch drawing media to description essay writing skills and to determine the effect of using sketch drawing media on writing essay writing skills for third grade students at SDN 50 Bulu Datu Palopo City. This study used a design research or design Quasi Experimental Design with Nonequivalent Control Group Design research techniques and quantitative approaches. The research instruments used were observation, tests, and documentation. The results showed that learning without image media had an effect on the provision of media drawing sketches on writing essay writing skills of class III SDN 50 Bulu 'Datu students in Palopo City by testing the similarity of the two final conditions between the control class and experimental class, obtained by the combined standard deviation $(d s g)=8.1430$ and Calculate $=10.5367$ and $Z_{\text {tabel }}=1.96$. Where is the significance level $\alpha=0.05$. Because $Z_{\text {hitung }}>Z_{\text {tabel }}$ then $H_{0}$ is rejected and $H_{1}$ is accepted. That is, the average value of understanding the experimental class concept is better than the control class. So it can be concluded that the provision of sketch drawing media can improve the essay writing skills of class III students of SDN 50 Bulu 'Datu Palopo City. The results ofdata analysis carried out after applying different image media in the control class and experimental class, it appears that the value of the essay writing skills of the two classes is significantly different. This means that the experimental class and the control class have significant differences.
\end{abstract}

Keywords: Sketch drawing media, essay description.

\begin{abstract}
Abstrak
Penelitian ini bertujuan adalah untuk mengetahui bentuk penerapan penggunaan media gambar sketsa terhadap keterampilan menulis karangan deskripsi dan untuk mengetahui pengaruh penggunaan media gambar sketsa terhadap keterampilan menulis karangan deskripsi pada siswa kelas III di SDN 50 Bulu Datu Kota Palopo. Penelitian ini menggunakan penelitian desain atau rancangan Quasi Experimental Design dengan teknik penelitian Nonequivalent Control Group Design dan pendekatan kuantitatif. Adapun instrumen penelitian yang digunakan adalah observasi, tes, dan dokumentasi. Hasil penelitian menunjukkan bahwa pembelajaran tanpa media gambar memberikan pengaruh terhadap pemberian media gambar sketsa terhadap keterampilan menulis karangan deskripsi siswa kelas III SDN 50 Bulu' Datu Kota Palopo dengan uji kesamaan dua rata-rata kondisi akhir antara kelas kontrol dan kelas eksperimen, diperoleh deviasi standar gabungan $(\mathrm{dsg})=8,1430 \mathrm{dan} Z_{\text {hitung }}=10,5367 \mathrm{dan} Z_{\text {tabel }}=$ 1,96. Dimana taraf signifikan $\alpha=0,05$. Karena $Z_{\text {hitung }}>Z_{\text {tabel }}$ maka $H_{0}$ ditolak dan $H_{1}$ diterima. Artinya, rata-rata nilai pemahaman konsep kelas eksperimen tergolong baik dari kelas kontrol. Sehingga dapat disimpulkan bahwa pemberian media gambar sketsa dapat meningkatkan keterampilan menulis karangan deskripsi siswa kelas III SDN 50 Bulu' Datu Kota Palopo. Hasil analisis data yang dilakukan setelah diterapkan media gambar yang berbeda pada kelas kontrol dan kelas eksperimen, terlihat bahwa nilai keterampilan menulis karangan deskripsi kedua kelas tersebut berbeda secara nyata. Artinya kelas eksperimen dan kelas kontrol memiliki perbedaan yang cukup signifikan.
\end{abstract}

Kata Kunci,: Media gambar sketsa, Karangan Deskripsi. 


\section{PENDAHULUAN}

Pendidikan merupakan proses pembelajaran yang dengan sadar dilakukan oleh seseorang atau kelompok dengan tujuan untuk mengubah cara berpikir, bersikap, dan berprilaku demi pendewasaan dirinya dan orang lain (Basilius R. Werang, 2015:15). Pengertian secara psikologis belajar merupakan suatu proses perubahan yaitu perubahan tingkah laku sebagai hasil dari interaksi dengan lingkungannya dalam memenuhi lingkungan hidupnya (Slameto 2015 : 2). Media adalah segala sesuatu yang dapat digunakan untuk menyalurkan pesan dari pengirim ke penerima sehingga dapat merangsang pikiran, perasaan, perhatian dan minat serta perhatian siswa sedemikian rupa sehingga proses belajar terjadi (Arief Sadiman, dkk, 2012:7).

Bahasa Indonesia perlu diterapkan kepada siswa di sekolah dasar untuk mempertajam kepekaan perasaan siswa, melatih kreativitas berpikir, dan daya khayal serta berkomunikasi dengan baik. Komunikasi merupakan proses penyampaian pesan yang dapat dilakukan secara lisan maupun tulisan (Rustan \& Subhan, 2018). Dalam proses komunikasi terdapat empat keterampilan yang berbeda namun saling berhubungan, komponen keterampilan berbahasa tersebut diantaranya yaitu menyimak, berbicara, membaca, dan menulis. Pada jenjang pendidikan sekolah dasar keterampilan menulis yaitu keterampilan yang akan dipelajari.

Menulis adalah salah satu dari empat keterampilan berbahasa yakni: menyimak, berbicara, membaca, dan menulis sendiri. Setiap keterampilan mempunyai hubungan yang erat dengan yang lainnya dalam memperoleh keterampilan berbahasa. Menulis merupakan suatu keterampilan berbahasa yang dipergunakan untuk berkomunikasi secara tidak langsung (Nurhadi Roekhan, 2010: 213-214). Tujuan menulis berdasarkan defenisi tersebut adalah dengan adanya menulis kita bisa mengekspresikan perasaan lewat tulisan (Patmawati, 2018). Menulis diharapkan mampu mengarahkan siswa mengembangkan sumber dayanya dan menjadikan pembelajaran menulis lebih bermakna berharga bagi siswa. Selanjutnya, diharapkan dapat mengantarkan siswa menjadi penulis dan pemikir yang baik, serta mandiri (Solchan dkk, 2014: 7.34).

Tarigan dalam jurnal Primary dalam kegiatan menulis diperlukan pengetahuan yang luas dan pola pikir yang logis. Dalam kegiatan menulis ini penulis haruslah terampil memanfaatkan grafologi, struktur bahasa dan ko sa kata (Iskandar, 2018). Kesalahan dalam struktur kalimat, kosa kata dan penggunaan ejaan menyebakan kalimat menjadi rancu yang berakibat pada kesalahan penafsiran maksud kalimat yang disampaikan (Rustan, 2016). PiJIES: Pedagogik Journal of Islamic Elementary School 
Keterampilan menulis dapat dikuasai melalui latihan atau praktik yang banyak dan teratur (Nugraheti Sismulyasih Sb, 2015 :64-65).

Salah satu bagian dari menulis adalah menulis karangan. Ada beberapa jenis karangan diantaranya: (1) karangan deskriptif, (2) karangan persuasif, (3)karangan argumentasi, dan (4) karangan narasi (Firman, 2015: 31). Alwi dalam buku Sukirman Nurdjan menyatakan karangan merupakan rentetan kalimat yang berkaitan yang menghubungkan proposisi yang satu dengan proposisi lain sehingga membentuk kesatuan yang cerita, buah pena, ciptaan, gubahan, cerita mengada-ada, dan hasil rangkaian (Nurdjan \& Rustan, 2010). Deskripsi bertujuan melukiskan atau memberikan gambaran terhadap sesuatu dengan sejelas-jelasnya sehingga pembaca seolah-olah melihat, mendengar, membaca, atau merasakan hal yang dideskripsikan (Sukirman Nurdjan, 2014 : 100)

Gerlach \& Ely dalam buku Azhar Arsyad mengatakan bahwa media apabila dipahami secara garis besar adalah manusia, materi, atau kejadian yang membangun kondisi yang membuat siswa mampu memperoleh pengetahuan, keterampilan, atau sikap. Dalam pengertian ini, guru, buku teks, dan lingkungan sekolah merupakan media. Secara khusus, pengertian media dalam proses belajar mengajar cenderung diartikan sebagai alat-alat grafis, photografis, atau elektronis untuk menangkap, memproses, dan menyusun kembali informasi visual atau verbal, (Azhar Arsyad, 2013: 3). Media dapat mewakili apa yang kurang mampu guru ucapkan melalui katakata atau kalimat tertentu. Bahkan keabstrakan bahan dapat dikonkretkan dengan kehadiran media. Dengan demikian, anak didik lebih mudah mencerna bahan daripada tanpa bantuan media, (Syaiful Bahri Djamarah dan Aswan Zain, 2012 : 136-137).

Media pembelajaran adalah suatu alat yang akan membantu kemudahan, kelancaran, serta keberhasilan proses belajar sebagaimana yang diharapkan Djahiri (dalam Ahmad Susanto, 2014 : 314). Bentuk alat komunikasi yang dapat digunakan untuk menyampaikan informasi dari sumber ke siswa secara terencana sehingga tercipta lingkungan belajar yang kondusif dimana penerimanya dapat melakukan proses belajar secara efisien dan efektif Menurut (Hamzah \& Nina Lamatenggo, 2011 : 122). Media adalah alat yang digunakan untuk menunjang suatu pembelajaran sehingga pembelajaran tersebut akan membantu siswa untuk lebih konsentrasi dalam prose belajar mengajar Menurut (Rusman, 2013 : 170).

Media gambar adalah suatu penyajian secara visual yang menggunakan titik-titik, garis-garis, gambar-gambar, dan tulisan atau simbol visual untuk mengihtisarkan, menggambarkan, dan merangkum ide data atau kejadian 
Menurut (Daryanto, 2010 : 19). Menurut Finoza dalam buku Sukirman Nurdjan dan Edhy Rustan karangan deskripsi adalah bentuk tulisan yang bertujuan memperluas pengetahuan dan pengalaman pembaca dengan jalan melukiskan hakikat objek yang sebenarnya.

Karangan deskripsi memiliki ciri-ciri seperti:1) Melukiskan atau menggambarkan objek, 2) Berisi rincian-rincian objek, 3) Membuat pembaca atau pendengar merasakan sendiri atau mengalami sendiri, dan 4) Hasil penyerapan panca indera (La Ode Rahim Aljatila, 2015). Nurgiyantoro dalam Iskandarwassid dan Dadang Sunendar berpendapat bahwa penilaian yang dilakukan terhadap karangan siswa biasanya bersifat holistis, impresif, dan selintas, maksudnya adalah penilaian yang bersifat menyeluruh berdasarkan kesan yang diperoleh dari membaca karangan secara selintas. Penilaian yang demikian jika dilakukan oleh beberapa ahli yang berpengalaman memang, sedikit banyak, dapat dipertanggungjawabkan. Akan tetapi, keahlian itu belum tentu dimiliki oleh para pengajar disekolah. Dalam kaitan dengan penilaian karangan, berikut ini beberapa kriterianya:1) Kualitas dan ruang lingkup isi, 2) Organisasi dan penyajian isi, 3) Komposisi, 4) Gaya dan bentuk bahasa, 5) Mekanik: tata bahasa, ejaan, tanda baca, 6) Kerapian tulisan dan kebersihan (Iskandarwassid dan Dadang Sunendar, 2013 : 208-209). Dalam penelitian ini peneliti menggunakan media gambar sketsa untuk meningkatkan keterampilan menulis karangan deskripsi siswa, oleh karena itu penelitian ini bertujuan : 1) Untuk mengetahui bentuk penerapan penggunaan media gambar sketsa terhadap keterampilan menulis karangan deskripsi kelas III di SDN 50 Bulu' Datu Kota Palopo. 2) Untuk mengetahui pengaruh penggunaan media gambar sketsa terhadap keterampilan menulis karangan deskripsi siswa kelas III di SDN 50 Bulu' Datu Kota Palopo

\section{METODE PENELITIAN}

Penelitian ini menggunakan metode Eksperimen. Penelitian ini dilakukan dengan mengukur perubahan yang muncul pada kelompok. Desain yang digunakan adalah desain atau rancangan Quasi Experimental Design dengan teknik penelitian Nonequivalent Control Group Design.. Penelitian ini dilakukan di SDN 50 Bulu' Datu, beralamat di jalan Kakatua/Perumnas kelurahan Rampoang kota Palopo, provinsi Sulawesi Selatan. Populasi dalam peneitian ini yaitu seluruh siswa kelas I-VI jumlahnya 306 dan yang menjadi sampel adalah kelas III SDN 50 Bulu' Datu Kota Palopo. Data yang diperoleh dianalisis dengan statistik deskriptif dan statistik inferensial. Uji syarat analisis terdiri dari uji normalitas dan uji homogenitas, uji kesamaan beda rata-rata

PiJIES: Pedagogik Journal of Islamic Elementary School 
Berdasarkan perhitungan data kelas kontrol sebelum perlakuan, diperoleh signifikansi $=0,247$ sedangkan pada data kelas eksperimen sebelum perlakuan diperoleh signifikan = 0,708 ( perhatikan lampiran 19 uji normalitas ). Dari hasil yang diperoleh ternyata keduanya lebih besar dari $\alpha$ sehingga dapat disimpulkan kelas kontrol dan kelas eksperimen sebelum perlakuan berasal dari populasi yang berdistribusi normal karena memenuhi syarat kriteria pengujian normalitas, uji Homogenitas dimaksudkan untuk mengetahui apakah data yang diteliti mempunyai varians yang homogen dengan kriteria pengujian, untuk menguji hipotesis digunakan uji beda dua rata-rata.

\section{HASIL PENELITIAN}

1. Penerapan Penggunaan media gambar sketsa dalam menulis karangan deskripsi siswa kelas III SDN 50 Bulu' Datu Kota Palopo

Proses penerapan media gambar sketsa dalam menulis karangan deskripsi siswa pada mata pelajaran bahasa Indonesia proses penerapan ini berlangsung pada saat siswa memasuki kelas sampai berakhirnya penerapan pembelajaran. Guru memasuki kelas dengan mengucap salam dan bertanya kabar siswa, adapun proses pembelajaran hari ini pendidik akan menggunakan media gambar sketsa untuk menarik perhatian siswa, meningkatkan daya khayal serta menghilangkan rasa bosan agar dapat mengemukakan idenya dalam bentuk tulisan, dalam penerapan media gambar sketsa ini terdapat beberapa tahapan yaitu mulai dari guru menyampaikan kepada siswa bahwa pembelajaran akan dilakukan dengan menggunakan media gambar sketsa, siswa tampak antusias mendengarkan apa yang telah disampaikan, kemudian guru menjelaskan karangan deskri psi setelah itu guru membagikan media gambar sketsa lalu siswa mengamati gambar sketsa yang dibagikan tadi kemudian guru membacakan contoh cerita yang dibuat berdasarkan gambar selanjutnya siswa mendengarkan guru membaca cerita dan dilanjutkan dengan tanya jawab tentang cerita.

Kemudian guru membagikan media gambar kedua setelah itu siswa ditugaskan membuat cerita berdasarkan gambar sketsa yang dibagikan. Gambar yang dibagikan kepada siswa merupakan gambar yang berhubungan dengan kehidupan sehari-hari yaitu gambar yang bertema gotong royong, tema ini dipilih untuk memudahkan siswa membuat karangan karena dialami dalam kehidupan sehari-hari sehingga siswa dapat membayangkan apa yang terjadi dalam gambar dan dapat dideskripsikan dalam bentuk karangan deskripsi. Setelah selesai, karangan dikumpul dimeja guru untuk selanjutnya diperiksa. Kemudian guru menutup pelajaran dengan memberi salam. 
190 | Anriyani

2. Pengggunaan media gambar sketsa berpengaruh terhadap keterampilan menulis karangan deskripsi siswa kelas III SDN 50 Bulu' Datu kota Palopo.

Setelah pemberian Pre-test, kemudian diterapkan pembelajaran yang berbeda pada kelas kontrol dan kelas eksperimen. Pada kelas kontrol menggunakan pembelajaran tanpa media gambar sedangkan kelas eksperimen pembelajaran menggunakan media gambar sketsa, pada proses akhir pembelajaran, diberikan post-test (tes kemampuan akhir) pada siswa untuk mengetahui apakah terdapat perbedaan antara keterampilan menulis karangan deskripsi pada kelas kontrol dengan kelas eks perimen. Dari posttest diperoleh nilai rata-rata kelas kontrol yang menggunakan pembelajaran konvensional/tanpa perlakuan yaitu 62,92 sedangkan nilai rata-rata kelas eksperimen setelah diterapkannya media gambar sketsa yaitu 80,08. Hasil analisis data yang dilakukan setelah diterapkan media gambar yang berbeda pada kelas kontrol dan kelas eksperimen, terlihat bahwa nilai keterampilan menulis karangan deskripsi kedua kelas tersebut berbeda secara nyata. Artinya kelas eksperimen dan kelas kontrol memiliki perbedaan yang cukup signifikan.

Selanjutnya jika skor pre-tes kelas kontrol dikelompokkan ke dalam lima kategori maka diperoleh tabel distribusi frekuensi dan persentase pretest kelas kontrol sebagai berikut:

Tabel 4.2 Perolehan Persentase Hasil Pre-test Kelas Kontrol

\begin{tabular}{ccccc}
\hline No & Nilai Angka & Kategori & Frekuensi & Persentasi (\%) \\
\hline 1 & $80-100$ & Sangat Baik & 0 & $0 \%$ \\
2 & $70-79$ & Baik & 3 & $12 \%$ \\
3 & $60-69$ & Cukup & 10 & $38 \%$ \\
4 & $50-59$ & Kurang & 10 & $38 \%$ \\
5 & $0-49$ & Sangat Kurang & 3 & $12 \%$ \\
\hline \multicolumn{2}{c}{ Jumlah } & & $\mathbf{2 6}$ & $\mathbf{1 0 0 \%}$ \\
\hline
\end{tabular}

Berdasarkan tabel 4.2 tersebut dapat dilihat bahwa dari 26 siswa pada kelas kontrol, siswa (12\%) dikategorikan baik, 10 siswa (38\%) dikategorikan cukup, 10 siswa (38\%) dikategorikan kurang, dan 3 siswa (12\%) dikategorikan sangat kurang.

PiJIES: Pedagogik Journal of Islamic Elementary School 
Selanjutnya jika skor pre-tes kelas kontrol dikelompokkan ke dalam lima kategori maka diperoleh tabel distribusi frekuensi dan persentase posttest kelas kontrol sebagai berikut:

Tabel Perolehan Persentase Hasil Post-test Kelas Kontrol

\begin{tabular}{ccccc}
\hline No & Nilai Angka & Kategori & Frekuensi & Persentasi (\%) \\
\hline 1 & $80-100$ & Sangat Baik & 2 & $8 \%$ \\
2 & $70-79$ & Baik & 4 & $16 \%$ \\
3 & $60-69$ & Cukup & 11 & $42 \%$ \\
4 & $50-59$ & Kurang & 9 & $34 \%$ \\
5 & $0-49$ & Sangat Kurang & 0 & $0 \%$ \\
\hline
\end{tabular}

Jumlah

26

$100 \%$

Berdasarkan tabel 4.4 tersebut dapat dilihat bahwa dari 26 siswa pada kelas kontrol, 2 siswa (8\%) dikategorikan sangat baik, 4 siswa (16\%) dikategorikan baik, 11 siswa (42\%) dikategorikan cukup, dan 9 siswa (34\%) dikategorikan kurang.

Selanjutnya jika skor pre-tes kelas kontrol dikelompokkan ke dalam lima kategori maka diperoleh tabel distribusi frekuensi dan persentase pretest kelas eksperimen sebagai berikut:

Tabel 4.5 Perolehan Persentase Hasil Pre-test Kelas Eksperimen

\begin{tabular}{ccccc}
\hline No & Nilai Angka & Kategori & Frekuensi & Persentasi (\%) \\
\hline 1 & $80-100$ & Sangat Baik & 0 & $0 \%$ \\
2 & $70-79$ & Baik & 9 & $37 \%$ \\
3 & $60-69$ & Cukup & 9 & $37 \%$ \\
4 & $50-59$ & Kurang & 6 & $26 \%$ \\
5 & $0-49$ & Sangat Kurang & 0 & $0 \%$ \\
\hline \multicolumn{7}{c}{ Jumlah } & $\mathbf{2 4}$ & $\mathbf{1 0 0 \%}$
\end{tabular}

Berdasarkan tabel 4.5 tersebut dapat dilihat bahwa dari 24 siswa pada kelas eksperimen, 9 siswa (37\%) dikategorikan baik, 9 siswa (37\%) dikategorikan cukup, dan 6 siswa (25\%) dikategorikan kurang. 
Selanjutnya jika skor pre-tes kelas kontrol dikelompokkan ke dalam lima kategori maka diperoleh tabel distribusi frekuensi dan persentase posttest kelas eksperimen sebagai berikut:

Tabel Perolehan Persentase Hasil Post-test Kelas Eksperimen

\begin{tabular}{cclcc}
\hline No & Nilai Angka & Kategori & Frekuensi & Persentasi (\%) \\
\hline 1 & $80-100$ & Sangat Baik & 16 & $67 \%$ \\
2 & $70-79$ & Baik & 5 & $21 \%$ \\
3 & $60-69$ & Cukup & 3 & $12 \%$ \\
4 & $50-59$ & Kurang & 0 & $0 \%$ \\
5 & $0-49$ & Sangat Kurang & 0 & $0 \%$ \\
\hline \multicolumn{2}{c}{ Jumlah } & & $\mathbf{2 4}$ & $\mathbf{1 0 0 \%}$ \\
\hline
\end{tabular}

Berdasarkan tabel tersebut dapat dilihat bahwa dari 24 siswa pada kelas eksperimen, 16 siswa (67\%) dikategorikan baik, 5 siswa (21\%) dikategorikan baik, 3 siswa (12\%) dikategorikan cukup.

\section{PEMBAHASAN PENELITIAN}

Sebelum proses pembelajaran dilakukan, diberikan pre-test (tes kemampuan awal) kepada siswa untuk mengetahui keterampilan menulis siswa sebelum diadakannya pembelajaran. Pada pemberian soal Pre-tes kelas kontrol diperoleh rata-rata 58,42 (pada lampiran 19) dan kelas eksperimen 65,12. (pada lampiran 19) Dapat disimpulkan bahwa tidak berbeda secara signifikan antara kelas Kontrol dan kelas Eksperimen.

Setelah pemberian Pre-test, kemudian diterapkan pembelajaran yang berbeda pada kelas kontrol dan kelas eksperimen. Pada kelas kontrol menggunakan pembelajaran tanpa media gambar sedangkan kelas eksperimen pembelajaran menggunakan media gambar sketsa, pada proses akhir pembelajaran, diberikan post-test (tes kemampuan akhir) pada siswa untuk mengetahui apakah terdapat perbedaan antara keterampilan menulis karangan deskripsi pada kelas kontrol dengan kelas eksperimen. Dari posttest diperoleh nilai rata-rata kelas kontrol yang menggunakan pembelajaran konvensional/tanpa perlakuan yaitu 62,92 sedangkan nilai rata-rata kelas eksperimen setelah diterapkannya media gambar sketsa yaitu 80,08. Hasil analisis data yang dilakukan setelah diterapkan media gambar yang berbeda pada kelas kontrol dan kelas eksperimen, terlihat bahwa nilai keterampilan menulis karangan deskripsi kedua kelas tersebut berbeda secara nyata.

PiJIES: Pedagogik Journal of Islamic Elementary School 
Artinya kelas eksperimen dan kelas kontrol memiliki perbedaan yang cukup signifikan.

Terjadinya perbedaan keterampilan menulis karangan deskripsi siswa tersebut disebabkan karena, adanya perbedaan perlakuan pada dua kelas yaitu eksperimen yang menggunakan media gambar dan kelas kontrol yang tidak diberikan perlakuan apapun pada pembelajaran bahasa Indonesia. Dimana keterampilan menulis karangan deskripsi siswa pada hasil post-test setelah adanya perlakuan atau diberikan media gambar lebih meningkat dari pada hasil post-test pada kelas kontrol yang tidak diberikan perlakuan.

Berdasarkan hasil observasi pada kelas eksperimen mengenai hasil observasi aktivitas siswa dalam pembelajaran, pada pertemuan awal hingga akhir menunjukkan adanya peningkatan aktivitas, pada pertemuanpertemuan awal masih terdapat hambatan dalam pengelolaan pembelajaran tersebut, namun seiring berjalannya waktu peningkatan aktivitas siswa, hal ini dibuktikan dengan hasil pengamatan aktivitas siswa pada kelas eksperimen yang menunjukkan peningkatan pada setiap pertemuan.

Berdasarkan hasil analisis statistik pada uji hipotesis dengan menggunakan uji-Z diperoleh data hasil akhir $Z_{\text {hitung }}=10,5367 ; Z_{\text {tabel }}=1,96$ dengan taraf signifikan $\alpha=0,05$. Karena $Z_{\text {hitung }}>Z_{\text {tabel }}$ maka $\mathrm{H}_{0}$ ditolak dan $\mathrm{H}_{1}$ diterima. Sesuai dengan hipotesis pada BAB 1 dikatakan $\mathrm{H}_{1}$ berarti terdapat pengaruh dalam penggunaan media gambar sketsa terhadap keterampilan menulis karangan deskripsi siswa kelas III SDN 50 Bulu' Datu Kota Palopo yang dalam hal ini memberikan pengaruh positif dengan meningkatkan keterampilan menulis karangan deskripsi.

Berdasarkan hasil analisis yang diperoleh, cukup mendukung teori yang telah dikemukakan Hamalik bahwamedia pembelajaran dalam proses belajar mengajar dapat membangkitkan keinginan dan minat yang baru, membangkitkan motivasi dan rangsangan kegiatan belajar, dan bahkan membawa pengaruh-pengaruh psikologis terhadap siswa. Penggunaan media pembelajaran pada tahap orientasi pembelajaran sangat membantu keefektivan proses pembelajaran dan penyampaian pesan dan isi pelajaran pada saat itu. Selain membangkitkan motivasi dan minat siswa, media pembelajaran juga dapat membantu siswa meningkatkan pemahaman, menyajikan data dengan menarik dan terpercaya, memudahkan penafsiran data, dan mendapatkan informasi (Azhar Arsyad, 2015: 19). Purwanto dan Alim (2007: 63) mengemukakan bahwa "penggunaan media gambar untuk melatih anak menentukan pokok pikiran yang mungkian akan menjadi karangan-karangan". Guru dalam menyampaikan materi pelajaran hendaknya menggunakan media pendidikan yang menarik dan membantu 
pemahaman siswa. Selama ini guru terkesan dalam menyampaikan materi pelajaranlebih senang dengan menggunakan metode ceramah yang kurang menarik bagi siswa (Budiyanto 2009). Tarigan (2012: 210) mengemukakan bahwa mengarang melalui gambar seri berarti melatih dan mempertajam daya imajinasi siswa. Gambar secara garis besar dapat dibagi pada tiga jenis yakni sketsa, lukisan, dan foto yang dikemukakan oleh Muhadi. Sketsa atau bias disebut juga sebagai gambar garis (stick figuran), yakni gambar sederhana sederhana atau draf kasar yang melukiskan bagian-bagian pokok suatu objek tanpa detail.

Teori yang dikemukakan oleh Daryanto Media gambar foto merupakan salah satu media pengajaran yang didapat dari berbagai sumber misalnya surat kabar, majalah, brosur, buku dan lainnya yang dapat digunakan oleh guru secara efektif dalam kegiatan belajar, mengajar pada setiap jenjang pendidikan dan berbagai disiplin ilmu (Sari Embun dan Mardiah Astuti, 2015: 86).

\section{PENUTUP}

Berdasarkan analisis data dan pembahasan hasil penelitian dapat disimpulkan sebagai berikut 1) Penerapan media gambar sketsa diprint pada selembar kertas HVS, media menggambarkan tentang kegiatan gotong royong masyarakat, media dibagikan kepada setiap siswa kemudian media gambar dijadikan siswa sebagai acuan dalam membuat karangan deskripsi. 2) Media gambar sketsa berpengaruh terhadap keterampilan menulis karangan deskripsi siswa kelas III SDN 50 Bulu' Datu Kota Palopo dilihat dari hasil analisis data yang diperoleh setelah diterapkan media gambar sketsa yang berbeda pada kelas kontrol dan kelas eksperimen, terlihat bahwa nilai keterampilan menulis karangan deskripsi kedua kelas tersebut berbeda secara nyata. Artinya kelas eksperimen dan kelas kontrol memiliki perbedaan yang cukup signifikan. Yaitu dari post-test diperoleh nilai ratarata kelas kontrol yang menggunakan pembelajaran konvensional/tanpa perlakuan yaitu 62,92 sedangkan nilai rata-rata kelas eksperimen setelah diterapkannya media gambar sketsa yaitu 80,08.

\section{DAFTAR PUSTAKA}

Arsyad, Azhar. 2015.Media Pembelajaran, Cet. XVIII; Jakarta: PT Raja Grafindo Persada.

Aljatila, Rahim La Ode, Meningkatkan Keterampilan Menulis Karangan Deskriptif Melalui Model Kooperatif Tipe Round Table Pada Siswa Kelas X-1 SMAN 1 Kulisusu Barat, jurnal Humanika, SMAN 1 Kulisusu Barat, Vol. 3, nomor 15, 2015.

PiJIES: Pedagogik Journal of Islamic Elementary School 
Aswan Zain, dan Syaiful Bahri Djamarah, Strategi Belajar Mengajar, (Jakarta: PT Rineka Cipta, 2012 ), h. 136-137.

Budiyanto. (2009). Bahasa Indonesia Menjawab Tantangan. Balai Bahasa Jawa Tengah.

Daryanto, 2010. Media Pembelajaran, Yogyakarta: Gava Media.

Firman, 2015.Terampil Menulis Karya Ilmiah, Makassar: Aksara Timur.

Hamzah \& Nina Lamatenggo. 2011. Teknologi Komunikasi \& Informasi Pembelajaran, Jakarta: Bumi Aksara.

Iskandarwassid dan Dadang Sunendar. 2013. Strategi Pembelajaran Bahasa, Cet. IV; Bandung: PT Remaja Rosdakarya.

Iskandar, I. (2018). Peningkatan Kemampuan Menulis Deskripsi Dengan Strategi Modelling. Pedagogik Journal of Islamic Elementary School, 1(1), 91-104. https://doi.org/10.24256/pijies.v1i1.383

Nurdjan, S., \& Rustan, E. (2010). Kunci Sukses Berbahasa Indonesia. Palopo: Lembaga Penerbitan STAIN (LPS) STAIN Palopo.

Nurhadi. 2010. Dimensi-Dimensi dalam Belajar Bahasa Kedua, Bandung: Sinar Baru Algensindo.

Patmawati. (2018). Metode Eksperimental Learning dalam Pembelajaran Keterampilan Menulis Deskriptif pada Mahasiswa Pendidikan Guru Sekolah Dasar. Pedagogik Journal of Islamic Elementary School, 1(1), 110.

Purwanto. 2007. Keterampilan Dasar Menulis. Jakarta: Universitas Terbuka. Rusman. 2013. Pembelajaran Berbasis Teknologi Informasi dan komunikasi, Jakarta: Raja Grafindo Persada.

Nurdjan, S., \& Rustan, E. (2010). Kunci Sukses Berbahasa Indonesia. Palopo: Lebaga Penerbitan Stain Palopo.

Rustan, E. (2016). Analisis Penggunaan Bahasa Indonesia Laras Hukum Pada Putusan Perkara Ekonomi Syariah Pengadilan Agama Makassar. AlAmwal: Journal of Islamic Economic Law, 1(2), 166-176. https://doi.org/10.24256/alw.v1i2.278

Rustan, E., \& Subhan. (2018). Komunikasi Verbal Anak Pesisir Usia 7-8 Tahun Pada Transakasi Penjualan Produk Kebudayaan Dengan Turis mancanegara. JPUD-Jurnal Pendidikan Usia Dini, 12(1), 12-28. https://doi.org/10.21009/JPUD.121 02

S. Sadiman, Arief, dkk., 2012 . Media Pendidikan, Jakarta: PT Rajagrafindo Persada.

Solchan dkk., 2014. Pendidikan Bahasa Indonesia di SD, Ed. 1. Banten: Universitas Terbuka.

Susanto, Ahmad. 2013. Teori Belajar dan Pembelajaran di Sekolah Dasar, Jakarta: Kencana Prenadamedia Group. 
196 | Anriyani

Sukirman. 2015. Cara Kreatif Menulis Karya Ilmiah, Makassar: Penerbit Aksara Timur.

Sismulyasih Sb, Nugraheti, Peningkatan Keterampilan Menulis Manuskrip Jurnal Ilmiah Menggunakan Strategi Synergetic Teaching Pada Mahasiswa PGSD UNNES, Jurnal Primary, Universitas Riau, Semarang, Vol. 4, Nomor 1, April 2015,

Slameto, 2015. Belajar dan Faktor-Faktor yang Mempengaruhinya Jakarta : Rineka Cipta

Sari Embun dan Mardiah Astuti, Pengaruh Penggunaan Media Gambar Terhadap Aktivitas Belajar Siswa Pada Mata Pelajaran IPA Materi Bumi dan Cuaca Di Madrasah Ibtidaiyah Najahiyah Palembang, Jurnal, Vol. 1, Januari 2015.

Tarigan, Henry Guntur, 2012. Menulis Sebagai Suatu Keterampilan Berbahasa. Bandung: Angkasa.

Werang, R Basilius, 2015. Menejemen Pendidikan di Sekolah, Yogyakarta:Media Akademi. 